\title{
3 THE IMPACTS OF INFORMATION TECHNOLOGY AND MANAGERIAL PROACTIVENESS IN BUILDING NET- ENABLED ORGANIZATIONAL RESILIENCE
}

\author{
Lih-Bin Oh \\ Hock-Hai Teo \\ National University of Singapore \\ Singapore
}

\begin{abstract}
The ability of an organization to generate variety is important for enhancing its organizational resilience when faced with volatilities from the environment. Using the context of integrated multichannel net-enabled retail organizations, we conceptualized organizational resilience as a higher-order capability comprising of two capabilities in terms of innovativeness and agility. Innovativeness reflects the scope aspect while agility represents the speed aspect of resilience. Based on a survey of 125 net-enabled retail organizations, we found that high levels of information technology capability and managerial proactiveness both significantly enhance organizational resilience. In addition, more resilient organizations perform better under turbulent environments. The construction of metrics to measure organizational resilience and the development of a structural model to elucidate the resilience building process and its performance consequences provide useful managerial and research implications.
\end{abstract}

Keywords Information technology, managerial proactiveness, net-enabled organization, multichannel retailing, organizational resilience, innovative capability, agility capability

\section{INTRODUCTION}

The retailing industry is currently operating in a dynamic environment and experiencing significant structural changes (Sambamurthy et al. 2003). To remain viable amidst this turbulence, retail organizations need to reexamine their organizational

Please use the following format when citing this chapter:

Oh, Lih-Bin, Teo, Hock-Hai, 2006, in International Federation for Information Processing (IFIP),

Volume 206, The Transfer and Diffusion of Information Technology for Organizational Resilience, eds. B. Donnellan, Larsen T., Levine L., DeGross J. (Boston: Springer), pp. 33-50. 
strategy, structure, and processes to keep themselves in pace with the competition. They need to nurture core competences for enhancing their organizational resilience to better withstand the environmental volatilities. In this digital economy, the chances of survival for retail businesses with only brick-and-mortar stores or pure Internet presence are ominous due to their low readiness to meet the expectations of the Net-generation consumers. Technology savvy consumers are increasingly demanding the ability to reach out to retailers using a wide range of technologies. They freely exchange information about products and retailers with other consumers through various interactive media. In addition, they expect retailers to offer presale, purchase, and after-sale services through a retail channel most convenient to them.

Such evolving environmental and consumer forces have intensified the imperative for retailers to expedite their transformations into multichannel net-enabled retail organizations (NERO). A net-enabled organization coordinates its activities and interacts with its stakeholders by exchanging messages over electronic networks (Straub and Watson 2001). It provides new channels for accessing customers and engages in innovation to offer new digital products or services that align the firm to its competitive environment (Wheeler 2002). Retail organizations such as Sears, CompUSA, Staples, Circuit City, and Best Buy in the United States and Tesco in the United Kingdom are certainly aware of the need for this e-transformation. These organizations and many others have been aggressively building up their cross-channel capabilities.

Undoubtedly, advancements in information technologies such as Internet connectivity, data warehousing, and customer relationship management systems are pivotal in presenting retailing firms with immense options to speed up the convergence of their retail channels. However, a fully integrated NERO is not about having separate physical and online retail channels with disparate business processes. Instead, it entails the effective exploitation of IT to integrate informational content and reconfigure processes in both channels.

Given the organizational complexity present in such a multichannel retailing firm, it is thus important to advance our understanding of the role in which IT affects the netenablement and capability-building processes. Recent thinking about the performance enhancing role of IT in organizations suggests that IT alone does not have a direct and unequivocal impact on firm performance. Rather, it is the complementary effect of IT with other organizational resources that results in improved organizational performance (Melville et al. 2004; Wade and Hulland 2004). A complementary organizational resource that is critical to reinforce the role of IT is the top management's level of proactiveness in formulating forward-looking strategies for organizational survival. This managerial characteristic is necessary for the organization to be able to sense and detect IT-enabled market opportunities to innovate rapidly under a turbulent environment.

In this study, we employ the context of business model and technology innovations in retail organizations to explore the impacts of IT and managerial proactiveness in enhancing organizational resilience for multichannel retailers. We also further examine the performance implications of net-enabled organizational resilience under turbulent environments. The rest of the paper is organized as follows. First, we provide a background of the study context and then introduce our conceptualization of organizational resilience and relate its relevance to NERO. Next, we discuss the hypotheses development and research method. Finally, we present the results and elaborate on our findings and contributions. 


\section{INTEGRATED RETAIL OPERATIONS MANAGEMENT}

According to The Economist (2004), one in five customers who enters a major U.S. department store has researched their purchase online. Half of the 60 million European consumers bought products offline after having investigated prices and details online. Multichannel consumers are found to spend more and are more loyal to retailers than single channel consumers (Forrester Research 2004). In response to consumers' expectations for multichannel shopping and the realization that physical retail channels are important in complementing the virtual channels, retail organizations are increasingly integrating their retail operations across channels.

After conducting an extensive review of the extant literature in traditional retailing, electronic commerce, and multichannel retailing (Keeney 1999; Mason et al. 1993; Samli 1989; Steinfield et al. 2002), we identified six areas of integrated retail operations management. These are briefly described below to provide a background for our study about building organizational resilience through innovations in retail channels.

- Integrated promotion is the advertising and publicity of one channel by the other channel in order to encourage customers of one to use the other as well as to increase awareness of both channels (Bahn and Fischer 2003). The physical store can be used as an advertising medium for the Website through brochures, receipts, carrying bags, posters and in-store promotions. Similarly, the Website can provide information about the locations of the physical stores and announcements of instore events (Steinfield et al 2002). Spillover effects are increased as promotions in each channel draw attention to the other.

- Integrated transaction information management involves collecting customers' online and offline transaction information, managing this integrated information, and making it available across multiple channels (Goersch 2002). Integrated transaction information would increase the richness of the information available and the quality of the services that can be provided based on this information. Retailers would be able to offer many value-added, personalized services such as customized Web pages, allowing customers to review their previous purchases and providing them with suggestions for future purchases.

- Integrated product and pricing information management involves ensuring the consistency of product and pricing information in both retail channels. This can be achieved by integrating product catalogs and ensuring that information related to product descriptions, product categories, prices, and discounts are consistent in both channels (Daniel and Wilson 2003). This would lead to a transparent flow of information between the processes and reduce consumers' confusion due to information inconsistencies.

- Integrated information access provides customers with the ability to access information available in one channel from another channel. With integrated information access, the Website can allow customers to search for products available in the physical store through an integrated database. Information on real-time inventory can be made available online so that customers will not make wasted trips 
to the store when the product is out of stock (Prasarnphanich and Gillenson 2003). Information kiosks at the physical store can help customers search for the availability and location of products from an online database while they are at the physical store (Gulati and Garino 2000).

- Integrated order fulfillment is the provision of support for customers to choose their preferred channel to complete their purchases. It includes allowing customers to use the online channel to order products and pick them up at local physical outlets and allowing gift coupons issued by the store to be redeemed either online or offline (Wallace et al. 2004). Consumers can also choose to make payment for their online purchases in the physical stores. An integrated product cataloging system can allow customers to quickly place online orders based on catalog numbers.

- Integrated customer service is the provision of services for customers to access service support in either channel. Self-serve Internet kiosks can be used for customers to access information on the Website or to place orders for out-of-stock items. Support can be provided at the physical stores for problems related to the online purchases such as allowing customers to return goods ordered online at the physical store (Prasarnphanich and Gillenson 2003). It also involves having an integrated communication channel where the Website provides after-sale services such as e-mail support for products bought in physical stores as well as real-time live chat, where online customers have access to in-store customer service assistants (Amit and Zott 2001).

\section{BUILDING BLOCKS OF ORGANIZATIONAL RESILIENCE}

The concept of resilience has its origins in the field of ecology and refers to "the magnitude of disturbance that a system can absorb before the system redefines its structure by changing the variables and processes that control behavior" (Gunderson 2000 , p. 426). This suggests that sustainability of a system is contingent on its variety. The degree of variety in a system guards against unexpected events in the environment. Therefore, a high degree of biological diversity ensures that no matter what the future unfolds, there will be at least some organisms that are well-suited to the new circumstances (Hamel and Valikangas 2003).

This capability to generate variety so that options are available to do things differently or do something else if the need arises is not only valuable to biological systems, but in fact to any system. Increasingly, organizations competing in dynamic environments are being viewed as systems making up of a collection of subsystems that are integrated to achieve organizational goals of the system (Sanchez 2001). Hence, the variety-generating capabilities of an organization are critical in enhancing its resilience (SubbaNarasimha 2001). The larger the variety of actions available to a system, the larger the variety of perturbations it is able to accommodate. If an organization's range of strategic alternatives is significantly narrower than the breadth of changes in the environment, the organization is going to be a victim of turbulence (Hamel and Vali- 
kangas 2003). By applying Ashby's (1958) "law of requisite variety" to organizations, Weick (1979) suggests that because of requisite variety, organizations have to keep sufficient diversity inside the organization to sense accurately the variety present in ecological changes outside it.

For the case of net-enabled retail organizations, we expect the ability to offer a variety of innovative products and services rapidly as being crucial to building up its organizational resilience. This is achieved by integrating the unique capabilities of an Internet Website and the advantages of a physical store such as personal contact and instant gratification. Our conceptualization of this form of net-enabled organizational resilience concurs with Hamel and Valikangas (2003), who define resilience as the capability of the organization to innovate with respect to organizational values, processes, and behaviors for continuous reconstruction. It also encompasses an organization's ability and capacity to endure systemic discontinuities and adapt to new risk environments (Starr et al. 2003).

Innovative capability represents one engine of organizational resilience building. In line with the thinking of Volberda (1996) on flexible organizational form, we believe that the speed to detect opportunities and threats, mobilize resources and generate innovations is equally important. Hence, we conceptualized organizational resilience as a second-order construct with two first-order constructs: innovative capability contributing to the scope aspect and agility capability contributing to the speed aspect of organizational resilience. Accordingly, we define net-enabled organizational resilience in this study as follows:

Net-enabled organizational resilience is the capacity of an organization to sense environmental changes and response swiftly with business model and technology innovations through the use of electronic networks to effectively withstand turbulence in the environment.

Organizations combine business model change and technology change to create innovations (Davila et al. 2005). In our study context, the value creation potential of innovations can be in the form of new products or services, new methods of distribution or marketing, tapping of new markets, or re-structuring transactions (Amit and Zott 2001). Access to resources from both channels provides the NERO an unprecedented opportunity to create new combination of product and service offerings and bundling. The improved quality of information about customers gathered allows the firm to come out with a variety of novel business processes that is not possible in a single-channel business. By innovating in the way business is done, firms can hope to differentiate themselves and gain additional market share.

Enhanced capabilities in innovativeness represent the scope of a firm's ability to launch competitive actions. Another area that is gaining prominence for firms to compete in a dynamic business environment is their ability to be agile (Oosterhout et al. 2005). Agility is the ability of a firm to continually sense and explore customer and marketplace enrichment opportunities and respond with the appropriate configurations of capabilities and capacities to exploit these opportunities rapidly and successfully (Sambamurthy et al. 2003). In order to actively respond to an accelerated and turbulent environment, firms need to develop competitive agility to be able to act quickly so as to manifest a high variety of competitive actions (Nayyar and Bantel 1994). An inte- 


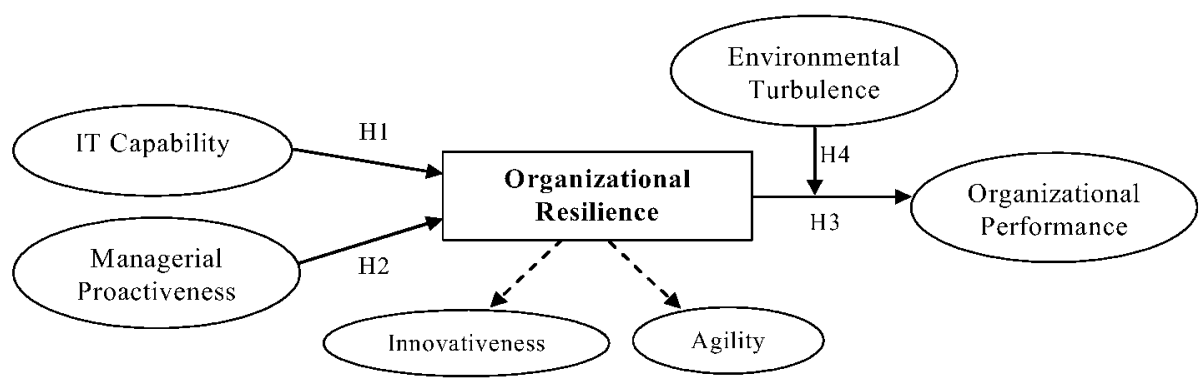

Figure 1. Research Model

grated retail channel provides the NERO with access to a pool of flexible resources that it can freely reallocate and reconfigure. This will enhance its ability to respond to competition quickly.

\section{RESEARCH MODEL AND HYPOTHESES DEVELOPMENT}

Figure 1 depicts the research model.

\subsection{Antecedents of Organizational Resilience}

Information technology serves as a critical antecedent for firms to generate more competitive actions through integrating their channels. In the retail industry, complementarities between IT, human, and business resources have been found to lead to sustainable performance advantages (Powell and Dent-Micallef 1997). An organization's IT capability can be defined as its organizational base of IT resources and capabilities. IT capabilities determine a firm's capacity for IT-based innovation as a result of available $I T$ resources and the ability to convert IT assets into strategic applications (Sambamurthy et al. 2003). In a multichannel NERO context, an organization's IT infrastructure capability can be regarded as the degree to which its computer and communication technologies, technical platforms and databases are shareable and reusable (Duncan 1995). This is necessary to enable business process synthesis and integration across disparate physical and organizational boundaries (Basu and Blanning 2003). Successful Internet-enabled business requires the seamless flow and sharing of order and customer information across all channels so that data about customers and stocks are synchronized across databases to ensure consistency. This enhances an organization's ability to innovate and respond to its environment rapidly. Therefore, we expect that firms with a higher level of IT infrastructure capabilities would be able to achieve a higher level of organizational resilience.

\section{H1: Information technology capability positively influences organizational} resilience. 
From the viewpoint of resource complementarity, it is equally critical for the top management to have the strategic foresight to integrate the IT and business processes effectively (Sambamurthy et al. 2003). The entrepreneurial characteristic of proactiveness provides the ability to generate competitive actions. Proactiveness refers to an organization's strategic orientation to seek new opportunities and introduce new products and services ahead of the competition (Venkatraman 1989). Firms that are proactive are the quickest to innovate and first to introduce new products and services (Lumpkin and Dess 1996). Strategic resilience is about continuously anticipating, making adjustments, and possessing the capacity to change before it is obvious (Hamel and Valikangas 2003). This suggests that strong proactive behavior by management is critical in enhancing organization resilience. In Miles and Snow's (1978) business strategy typology, prospectors are found to enact a more dynamic environment and to place more emphasis on innovation. Proactiveness is a distinguishing characteristic of prospector organizations (Sabherwal and Chan 2001). Hence, we expect firms that are more proactive in their strategic orientation would be able to achieve a higher level of organizational resilience.

\section{H2: Managerial proactiveness positively influences organizational resilience.}

\subsection{Impact of Organizational Resilience on Performance}

In our context, by enhancing its level of innovativeness through providing a greater range of new offerings to its customers, the organization can retain its existing customers as well as attract new customers. As a result, it increases its market share and profits. By being more agile, firms can act quickly so as to manifest a high variety of competitive actions (Nayyar and Bantel 1994). This is an essential capability for organizations operating in high-velocity industries with rapidly shifting competitive landscapes. In line with previous studies in marketing (e.g., Grewal and Tansuhaj 2001; Johnson et al. 2003) and manufacturing (e.g., Vickery et al. 1997), we hypothesize that organizational resilience will have a positive impact on organizational performance.

\section{H3: Organizational resilience positively influences organizational perfor- mance.}

Consistent with current theory (e.g., Grewal and Tansuhaj 2001), we posit that the impact of organizational resilience on organizational performance is contingent on the level of turbulence in the macro environment. This is because turbulent environments reward organizational resilience since such environments demand anticipating the unexpected and competing in uncertain conditions (Sambamurthy et al. 2003; Volberda 1996). Environmental turbulence increases the likelihood that organizational resilience would create valuable outcomes for the firm. This argument is premised on the notion of performance advantages accruing to a firm that is in strategic alignment with its environment (Zajac et al. 2000). Building organizational resilience through enhanced innovative capabilities and agility capabilities can be viewed as strategic options (Kogut and Zander 1996), which offer the firm a choice to pursue new opportunities leading to enhanced performance when the environment calls for them. Hence, the higher the environmental turbulence, the more likely these options will be valuable in enhancing firm performance (Sambamurthy et al. 2003). 


\section{H4: The relationship between organizational resilience and organizational performance is positively moderated by environmental turbulence.}

\subsection{Control Variables}

Following prior research on business value of IT and organizational performance, we expect that organizational performance would be influenced by its firm size and number of years since it first established a Website (net-enablement). Next, the extent to which a firm achieves superior performance through implementing various multichannel strategies would likely be affected by the size of the physical store network since a large chain store would have more advantages to tap into their extensive physical store infrastructure to complement their online activities. Furthermore, integration of some activities might be less important for certain retail industry sectors and this might influence the performance. These four factors were used as control variables for organizational performance.

\section{RESEARCH METHOD}

\subsection{Survey Data Collection}

The unit of analysis is retail organization with both physical store(s) and an online Website. The sampling frame was drawn from Dun and Bradstreet directories and included retail trade companies in Singapore with standard industrial classification (SIC) codes starting from 5211 through 5999. The final sampling frame comprises of 562 companies. The survey that was conducted between March and May 2005 employed a three-wave mailing procedures advocated by Dillman (1999). A survey package with a postage-paid return envelope was mailed to the top executive of each company. One week after the initial mailing, a reminder postcard was sent to the companies. After about another week, a complete survey package was remailed to them. After accounting for 20 undelivered packages, and discarding 8 incomplete responses, we obtained a final usable sample of 125 . The response rate of 24.5 percent is considered reasonable since the survey was unsolicited and involved participation of senior management. We motivated the respondents to provide valid data by offering a summary of the research results and an invitation to a free workshop on the research findings. These helped to ensure that respondents become professionally interested and committed to provide accurate data. We assessed nonresponse bias by verifying that early and late respondents did not significantly differ in their demographic characteristics and responses on principal constructs (Armstrong and Overton 1977). We also checked for existence of any common method bias with Harman's single-factor test since response comes from a single key informant (Podsakoff et al. 2003). We found no significant biases in our dataset. Table 1 shows our sample characteristics. 
Table 1. Characteristics of Survey Sample

\begin{tabular}{|c|c|c|c|}
\hline & Category & Number & $\%$ \\
\hline \multirow{4}{*}{$\begin{array}{l}\text { Respondent } \\
\text { Position }\end{array}$} & CEO, CFO, CIO, Managing Director & 80 & 64.0 \\
\hline & Sales and Marketing Directors/Managers & 29 & 23.2 \\
\hline & Executives & 10 & 8.0 \\
\hline & Others & 6 & 4.8 \\
\hline \multirow{9}{*}{$\begin{array}{l}\text { Retail } \\
\text { Industry } \\
\text { Sector }\end{array}$} & Apparels, Accessories and Jewelry & 23 & 18.4 \\
\hline & Cars and Automotive Products & 9 & 7.2 \\
\hline & Book and Stationery Stores & 5 & 4.0 \\
\hline & $\begin{array}{l}\text { Furniture, Home Furnishings and Building } \\
\text { Hardware }\end{array}$ & 13 & 10.4 \\
\hline & Eating and Drinking Places & 12 & 9.6 \\
\hline & Florists and Gifts Shop & 15 & 12.0 \\
\hline & Grocery Stores and Health Products & 13 & 10.4 \\
\hline & Home Appliances, Computers and Electronics & 25 & 20.0 \\
\hline & Departmental Stores and Other Merchandise & 10 & 8.0 \\
\hline \multirow{4}{*}{$\begin{array}{l}\text { Number of } \\
\text { employees }\end{array}$} & $<50$ & 77 & 61.6 \\
\hline & $50-100$ & 19 & 15.2 \\
\hline & $101-200$ & 14 & 11.2 \\
\hline & $>201$ & 15 & 12.0 \\
\hline \multirow{4}{*}{$\begin{array}{l}\text { Number of } \\
\text { physical } \\
\text { retail stores }\end{array}$} & $<5$ & 84 & 67.2 \\
\hline & $5-10$ & 16 & 12.8 \\
\hline & $11-20$ & 15 & 12.0 \\
\hline & $>20$ & 10 & 8.0 \\
\hline
\end{tabular}

\subsection{Operationalization of Constructs}

All constructs were measured on seven-point Likert-type scales. The four-item scale used to measure IT capability was adapted from Byrd and Turner (2000) to assess the firm's technical IT infrastructure in terms of communication network connectivity, inventory, and customer database integration. The three items used to measure managerial proactiveness were adopted from Sabherwal and Chan (2001), which was based on Venkatraman's (1989) strategic orientation of business enterprises (STROBE) scale. This scale assesses the proactive behavior of increasing capacity before competitors and being a first-mover to introduce products and services. Organizational resilience was conceptualized as a second-order construct comprising of two first-order constructs of innovative capability and agility capability. Due to the unavailability of scales suitable for our study context, the three-item scale used to measure innovative capability was 
self-developed based on conceptual developments by Amit and Zott (2001) and Hamel and Valikangas (2003). It assesses the net-enabled organization's ability to offer new services and products. The three items used to measure agility capability were selfdeveloped based on Sambamurthy et al. (2003), and measure the organization's ability to detect opportunities and respond quickly to business environment and competitor's market actions. We used a seven-item scale to measure environmental turbulence by assessing the organization's market and technological turbulence. This scale was adapted from Jaworski and Kohli (1993).

Many variables including productivity, efficiency, profitability, and competitive advantage have been used to measure IT-enabled organizational performance (Melville et al. 2004). Tallon et al. (2000) suggest that perceptual measures of firm performance correlate strongly with objective measures and in the absence of objective data on IT payoffs, executives' perceptions can identify areas where IT is creating value. Management assessments are generally consistent with secondary published performance data external to the organization. Following Wade and Hulland's (2004) recommendation that the dependent variable used to measure performance should incorporate a competitive assessment of performance, we measured organizational performance as an aggregated metric comprising of market share gains, net profits, revenue growth, return on investments, and return on assets, measured relative to major competitors.

\subsection{Control Variables}

Firm size was coded as the $\log$ of the number of employees, and net-enablement age was represented as the $\log$ of the number of years since the firm first established its Website, using year 2005 as a base. Industry sector was coded as a dummy variable for different industry sectors, while the size of the physical network was coded as the $l o g$ of the number of physical retail store(s).

\section{DATA ANALYSES AND RESULTS}

The structural equation modeling technique, partial least squares (PLS) as implemented in PLS-Graph Version 3.0, was used for data analyses (Chin 2001). It is an appropriate method for testing complex predictive research models (Joreskög and Wold 1982) as it can assess the measurement model (relationships between questions and constructs) within the context of the structural model (relationships among constructs). It maximizes the explanation of variance and prediction in the theoretical model, does not demand multivariate normal distributions, and is suitable for small sample size exploratory studies. Although a series of multiple regression analyses could be used to test our research model, PLS is a better approach as it can account for measurement errors in unobserved constructs and examine the significance of structural paths simultaneously. Furthermore, due to the lack of ability to account for measurement errors, techniques such as moderated regression are unable to accurately detect the strength of moderating effects between continuous variables (McClelland and Judd 1993). 


\subsection{Validity and Reliability of Organizational Resilience Construct}

Based on the conceptual model presented in Figure 1, two factors were created from indicators of innovative capability and agility capability to represent organizational resilience as a second-order construct. The factor analysis confirmed that the organizational resilience indicators loaded well onto the two corresponding factors: innovative capability and agility capability. As shown in Table 2 , this indicates good validity and reliability of the first-order factors.

As theorized earlier, organizational resilience is a higher-order construct across two dimensions of innovative capability and agility capability. The correlations between the two first-order factors are statistically significant and of high magnitude (Pearson's coefficient $=0.668, \mathrm{p}<0.001$ ). This suggests the existence of such a higher-order factor structure consistent with our conceptualization. The factor scores of the two first-order constructs were used to assess the validity and reliability of the second-order construct. As shown in Table 3, all structural coefficients exhibit significant critical ratios, providing evidence of convergent validity. The composite reliability was estimated from path loadings to be 0.773 , indicating sufficient reliability for the second-order construct. Therefore, on both theoretical and empirical grounds, our conceptualization of organizational resilience as a higher-order, multidimensional construct seems justified.

Table 2. Measurement Properties of First-Order Organizational Resilience Constructs

\begin{tabular}{|c|c|c|c|}
\hline Construct & Item & $\begin{array}{c}\text { Factor } \\
\text { Loading }\end{array}$ & $\begin{array}{c}\text { Cronbach's } \\
\text { Alpha }\end{array}$ \\
\hline \multirow{3}{*}{$\begin{array}{l}\text { Innovative } \\
\text { Capability } \\
\text { (IC) }\end{array}$} & $\begin{array}{l}\text { IC1: Provide unique products and services to } \\
\text { our customers. }\end{array}$ & 0.855 & 0.928 \\
\hline & IC2: Bundle products and services creatively. & 0.893 & \\
\hline & IC3: Offer new customer support services. & 0.859 & \\
\hline \multirow{3}{*}{$\begin{array}{l}\text { Agility } \\
\text { Capability } \\
\text { (AC) }\end{array}$} & $\begin{array}{l}\mathrm{AC} 1 \text { : Continually sense and detect customer } \\
\text { and marketplace opportunities. }\end{array}$ & 0.866 & 0.956 \\
\hline & $\begin{array}{l}\mathrm{AC} 2 \text { : Respond quickly to dynamic business } \\
\text { environment. }\end{array}$ & 0.882 & \\
\hline & $\begin{array}{l}\text { AC3: React rapidly to competitors' market } \\
\text { actions. }\end{array}$ & 0.911 & \\
\hline
\end{tabular}

Table 3. Estimation of the Second-Order Construct

\begin{tabular}{|l|l|c|c|c|}
\hline $\begin{array}{c}\text { Second-order } \\
\text { Construct }\end{array}$ & First-order Constructs & $\begin{array}{c}\text { Standard } \\
\text { Loading }\end{array}$ & $\boldsymbol{t}$-statistic & $\begin{array}{c}\text { Composite } \\
\text { Reliability }\end{array}$ \\
\hline $\begin{array}{l}\text { Organizational } \\
\text { Resilience } \\
(\text { RESILIENCE) }\end{array}$ & Innovative Capability (IC) & 0.798 & $7.015^{* * *}$ & 0.773 \\
\cline { 2 - 6 } & Agility Capability (AC) & 0.752 & $6.841^{* * *}$ & \\
\hline$* * * p<0.001$ & \multicolumn{4}{|l}{} \\
\hline
\end{tabular}


Table 4. Psychometric Properties and Descriptive Statistics of Measurement Model

\begin{tabular}{|c|c|c|c|c|c|}
\hline Construct & $\begin{array}{c}\text { Item } \\
\text { Loading }\end{array}$ & $\begin{array}{l}\text { Composite } \\
\text { Reliability }\end{array}$ & AVE & Mean & SD \\
\hline $\begin{array}{l}\text { IT Capability (IT) } \\
\text { IT1: Our Web-based systems are tightly linked to } \\
\text { our existing computer systems in the physical } \\
\text { stores via real-time communication networks. } \\
\text { IT2: The physical stores and the Website access to } \\
\text { a common inventory database. } \\
\text { IT3: The physical stores and the Websitc access } \\
\text { to common customcr databasc. } \\
\text { IT4: Information is shared seamlessly across our } \\
\text { organization, regardless of location. }\end{array}$ & $\begin{array}{l}0.916 \\
0.930 \\
0.881 \\
0.862\end{array}$ & 0.943 & 0.806 & 3.440 & 1.511 \\
\hline $\begin{array}{l}\text { Managerial Proactiveness (PROACT) } \\
\text { PROACT1: We generally increase capacity (i.c., } \\
\text { prepare to handle a greater volume of business) } \\
\text { before our competitors do the same. } \\
\text { PROACT2: We are usually the first ones to } \\
\text { introducc various products and/or services in the } \\
\text { market. } \\
\text { PROACT3: We adopt innovations early. }\end{array}$ & $\begin{array}{l}0.889 \\
0.957 \\
0.950\end{array}$ & 0.952 & 0.869 & 4.650 & 1.411 \\
\hline $\begin{array}{l}\text { Environmental Turbulence (ENV) } \\
\text { ENV1: Environmental changes in our industry are } \\
\text { very difficult to forccast. } \\
\text { ENV2: The business environment in which we } \\
\text { operate is continuously changing. } \\
\text { ENV3: In our kind of busincss, customers' } \\
\text { product preferenecs change a lot over time. } \\
\text { ENV4: Marketing practices in our product areas } \\
\text { are constantly changing. } \\
\text { ENV5: New product introductions are very } \\
\text { frequent in this market. } \\
\text { ENV6: The technology used to provide our } \\
\text { products and services changes rapidly. } \\
\text { ENV7: Many new products and scrvices ideas } \\
\text { have been made possible through technology } \\
\text { breakthroughs in this industry. }\end{array}$ & $\begin{array}{l}0.661 \\
0.766 \\
0.793 \\
0.814 \\
0.862 \\
0.736 \\
0.663\end{array}$ & 0.904 & 0.577 & 4.880 & 0.994 \\
\hline $\begin{array}{l}\text { Organizational Performance (PERFORM) } \\
\text { PERFORM1: Market share gains } \\
\text { PERFORM2: Net profits } \\
\text { PERFORM3: Revenue growth } \\
\text { PERFORM4: Return on investment } \\
\text { PERFORM5: Return on assets }\end{array}$ & $\begin{array}{l}0.809 \\
0.870 \\
0.897 \\
0.874 \\
0.894\end{array}$ & 0.939 & 0.756 & 4.420 & 0.915 \\
\hline
\end{tabular}

Table 5. Discriminant Validity of Reflective Constructs

\begin{tabular}{|l|r|r|r|r|r|}
\hline \multicolumn{1}{|c|}{ Construct } & \multicolumn{1}{c|}{ IT } & PROACT & RESILIENCE & ENV & PERFORM \\
\hline IT & 0.806 & & & & \\
\hline PROACT & 0.108 & 0.869 & & & \\
\hline RESILIENCE & 0.272 & 0.215 & 0.574 & & \\
\hline ENV & 0.070 & 0.123 & 0.098 & 0.577 & \\
\hline PERFORM & 0.208 & 0.403 & 0.215 & 0.052 & $\mathbf{0 . 7 5 6}$ \\
\hline
\end{tabular}




\subsection{Evaluating the Measurement Model}

We used three tests to determine the convergent validity and internal consistency of the four other reflective constructs in our model: item loading, composite reliability of constructs, and the average variance extracted (AVE) by construct. Table 4 presents the psychometric properties and descriptive statistics. All item loadings between an indicator and its posited underlying construct factor were greater than 0.7. Composite reliability of constructs all exceeded Nunnally and Bernstein's (1994) criterion of 0.7 , while the average variances extracted were above the recommended threshold of 0.5 , adequately demonstrating convergent validity. Table 5 reports the test for discriminant validity of reflective constructs. Diagonal elements are AVE for each construct, which, for discriminant validity, should be greater than the off-diagonal elements of the square of inter-construct correlations. All our constructs fulfilled these criteria.

\subsection{Testing the Structural Model}

With assurance of good psychometric properties in the measurement model, the PLS structural model was next assessed to determine its explanatory power and the significance of the hypothesized paths. The explanatory power of the structural model was determined based on the amount of variance in the endogenous constructs for which the model could account. To assess the moderating role of environment turbulence on the relationship between organizational resilience and firm performance using PLS, we followed the method proposed by Chin et al. (2003). First, product indicators for the interaction construct (RESILIENCE $\times$ ENV) were created by multiplying each of the two indicators for organization resilience (factor scores of IC and AC) with each of the seven indicators for environment turbulence (ENV1 to ENV7). Hence, the interaction construct comprises of 14 product indicators. A boot-strapping resampling procedure was used to estimate the standard errors and to determine the significance of the path coefficients.

Our variables in the research model could explain 32.5 percent of variance in performance. All hypotheses were supported. Both IT capability and managerial proactiveness significantly impact organizational resilience but the level of IT capability $(b=0.431, p<0.001)$ had a greater impact on organizational resilience compared to managerial proactiveness $(b=0.308, p<0.001)$. These two antecedents accounted for 37.8 percent of the variance in organizational resilience. Before including the moderating variable environmental turbulence into the structural model, we separately tested a base model whereby organizational resilience directly impacts organizational performance. This relationship is significant at $p<0.01$ but the variance explained for organizational performance in this base model is only 23.2 percent. This suggests that by adding environmental turbulence as a moderator into the model, we have substantially increased the variance explained in performance by 9.3 percent. In the full model, organizational resilience has a direct impact on organizational performance $(\mathrm{H} 3$ : $b=0.446, p<0.01$ ), but this relationship is significantly moderated by environmental turbulence (H4: $b=0.263, p<0.01)$. All control variables were insignificant at $p<$ 0.05 . 


\section{DISCUSSION}

This research attempts to understand the impacts of information technology and managerial proactiveness in nurturing net-enabled organizational resilience in the context of multichannel retail organizations. Drawing on the ecological survival perspective, we argue that creation of organizational resilience hinges on the firm's ability to generate variety in the organization. This is because formulating organizational strategy for turbulent environments requires the development of variety-generating capability in the organization (SubbaNarasimha 2001). The results from our empirical study demonstrate evidence to support this proposition.

Foremost, our findings explicate the roles of IT and managerial proactiveness in enhancing organizational resilience. We found that IT capability has a stronger impact on organizational resilience compared to managerial proactiveness. An integrated IT infrastructure across the organization links various units and provides a seamless flow of accurate, consistent, and timely information to employees and customers. Information is the key to formulating IT-enabled strategies for competing in turbulent environments. Hence, a high level of IT capability is a prerequisite to provide the foundation for developing core organizational competences. However, based on the organizational resource complementarity perspective, the business value of IT depends on the presence and influence of other organizational, business, and technical resources. Organizational resources such as organizational culture and human resource capability have been found to affect innovation and agility (Oosterhout et al. 2005). Increasingly, there is an expectation for organizations to exhibit an entrepreneurial orientation in order to achieve superior performance (Lumpkin and Dess 1996). In our research context of multichannel retailing, the degree of proactiveness is an essential entrepreneurial characteristic for executing managerial foresight to seize new opportunities in the competitive retailing environment.

Our results revealed that organizations attain resilience when they are able to sense environmental changes and respond swiftly with innovations in channel arrangements, products, and services. This results from the expansion of the repertoire of actions available to react to unforeseen threats and unanticipated changes in the environment. Organizations that are more resilient were found to exhibit better organizational performance. Furthermore, the findings also indicate that under turbulent environments, organizations with a higher level of organizational resilience achieve more superior performance. This highlights the point that organizations that have invested heavily in IT and manifest proactive behavior to build up their resilience capacity will be able to leverage on the strategic options of doing so when the opportunities arise or when crisis happens.

Before discussing the implications of our research, some limitations must be acknowledged. First, even though we have carried out statistical tests to address potential biases, interpretation of our results needs to take into consideration that data were collected through a single informant. Second, the dataset comprising of only Singaporean retail firms might limit the generalizability of our results. Third, we have developed and examined the notion of organizational resilience in the context of netenabled retail organizations. Our conceptualization of this construct in terms of innovative capabilities is based on a retailing context and hence this could reduce its 
applicability to other types of organizations. Finally, even though our sample size is of sufficient power to detect meaningful effects, future research should be conducted with a larger sample.

Despite these limitations, we believe that our substantial findings through this exploratory effort provide numerous implications for practice and future research. The validation that IT and proactiveness are complementary in building organizational resilience should serve as a reminder to managers that they need to ramp up the integrative capabilities of their IT infrastructure. The subunits and functional areas across the organizations should be tightly linked with IT to facilitate communications and information flow. This is critical for sensing opportunities and disruptive irregularities in the organization system. Next, our results also attest to the importance of cultivating a proactive behavior in the top management for building a resilient organization. Our conceptualization of organizational resilience as a higher-order construct comprising of innovative capability and agility capability provides some relevant managerial insights. The empirical validation of the metrics for this construct suggests that the level of resilience in an organization may be measured through assessing its innovative capabilities in making changes to its business model, products, and services as well as its agility capabilities in terms of how well it is able to sense and respond to environmental threats and opportunities. It is also noteworthy that the rewards for building resilience are greater for organizations existing in highly dynamic environments.

The development of a structural model to understand organizational resilience building a under turbulent environment is a significant theoretical contribution. This should serves as a useful first step in advancing our knowledge of the capabilitybuilding process of resilience and its performance implications. Our theoretical conceptualization of organizational resilience converges with Gunderson (2000)'s idea that the resilience of a system can be increased by increasing the buffering capacity of the system through nurturing sources of renewal (i.e., increasing scope through innovating) and mitigating the effects of unwanted variation in the system in order to shorten the return time to a desired equilibrium (i.e., increasing the response speed by being more agile). We find empirical support for our two-dimensional higher-order construct of organizational resilience. Nevertheless, we believe that organizational resilience is likely to be a multi-faceted construct that manifests itself differently under different context. The approach that we have employed in this research should be invaluable to future researchers who are interested in constructing multidimensional representations of organizational resilience in other net-enabled organizations to measure and understand the challenges involved in building this important organizational capability.

\section{References}

Amit, R., and Zott, C. "Value Creation in E-business," Strategic Management Journal (22), 2001, pp. 493-520.

Armstrong, J. S., and Overton, T. S. "Estimating Nonresponse Bias in Mail Surveys," Journal of Marketing Research (14), August 1977, pp. 396-402.

Ashby, W. "Requisite Variety and its Implications for the Control of Complex Systems," Cybernetica (1), 1958, pp. 83-99. 
Bahn, D. L., and Fischer, P. P. "Clicks and Mortar: Balancing Brick and Mortar Business Strategy and Operations with Auxiliary Electronic Commerce," Information Technology and Management (4), 2003, pp. 319-334.

Basu, A., and Blanning, R. "Synthesis and Decomposition of Processes in Organizations," Information Systems Research (14:14), 2003, pp. 337-355.

Byrd, T.A., and Turner, D.E. "Measuring the Flexibility of Information Technology Infrastructure: Exploratory Analysis of a Construct," Journal of Management Information Systems (17:1), Summer 2000, pp. 167-208.

Chin, W. W. PLS-Graph User's Guide Verison 3.0, Soft Modeling Inc., 2001.

Chin, W. W., Marcolin, B. L., and Newsted, P. R. "A Partial Least Squares Latent Variable Modeling Approach for Measuring Interaction Effects: Results from a Monte Carlo Simulation Study and an Electronic-Mail Emotion/Adoption Study," Information Systems Research (14:2), 2003, pp. 189-217.

Daniel, E. M., and Wilson, H. N. "The Role of Dynamic Capabilities in E-Business Transformation," European Journal of Information Systems (12), 2003, pp. 282-296.

Davila, T., Epstein, M. J., and Shelton, R. Making Innovation Work: How to Manage It, Measure It, and Profit from It, Upper Saddle River, NJ: Wharton School Publishing, 2005.

Dillman, D. Mail and Internet Surveys: The Tailored Design Method $\left(2^{\text {nd }}\right.$ ed.), New York: John Wiley, 1999.

Duncan, N. B. "Capturing Flexibility of Information Technology Infrastructure: A Study of Resource Characteristics and Their Measure,"Journal of Management Information Systems (12:2), Fall 1995, pp. 37-57.

The Economist. "A Perfect Market," May 15, 2004, pp. 3-5.

Forrester Research. "The State of Retailing Online 7.0," Cambridge, MA, 2004.

Goersch, D. "Multichannel Integration and Its Implications For Retail Web Sites," paper presented at the European Conference on Information Systems (ECIS), Gdansk, Poland, 2002.

Grewal, R., and Tansuhaj, P. "Building Organizational Capabilities for Managing Economic Crisis: The Role of Market Orientation and Strategic Flexibility," Journal of Marketing (65), April 2001, pp. 1-28.

Gulati, R., and Garino, J. "Get the Right Mix of Bricks and Clicks," Harvard Business Review (78:3), May/June 2000, pp. 107-114.

Gunderson, L. H. "Ecological Resilience: In Theory and Application," Annual Review of Ecological Systems (31), 2000, pp. 425-439.

Hamel, G., and Valikangas, L. "The Quest for Resilience," Harvard Business Review (81:9), September 2003, pp. 52-63.

Jaworski, B., and Kohli, A. "Market Orientation: Antecedents and Consequences," Journal of Marketing (57), July 1993, pp. 53-70.

Johnson, J. L., Lee, R. P., Saini, A., and Grohmann, B. "Market-Focused Strategic Flexibility: Conceptual Advances and an Integrative Model," Journal of Academy of Marketing Science (31:1), 2003, pp. 74-89.

Joreskög, K., and Wold, H. Systems Under Indirect Observation: Causality, Structure, and Prediction, Amsterdam: North-Holland, 1982.

Keeney, R. "The Value of Internet Commerce to the Customer," Management Science (45:4), April 1999, pp. 533-542.

Kogut, B., and Zander, U. "What Do Firms Do? Coordination, Identity, and Learning," Organization Science (7), 1996, pp. 502-518.

Lumpkin, G., and Dess, G. G. "Clarifying the Entrepreneurial Orientation Construct and Linking it to Performance," Academy of Management Review (21:1), 1996, pp. 135-172.

Mason, J. B., Mayer, M. L., and Wilkinson, J. B. Modern Retailing: Theory and Practice $\left(6^{\text {th }}\right.$ ed.), Homewood, IL: Irwin, 1993. 
McClelland, G., and Judd, C. "Statistical Difficulties of Detecting Interactions and Moderator Effects," Psychological Bulletin (114:2), 1993, pp. 376-390.

Melville, N., Kraemer, K., and Gurbaxani, V. "Review: Information Technology and Organizational Performance: An Integrative Model of IT Business Value," MIS Quarterly (28:2), June 2004, pp. 283-322.

Miles, R. E., and Snow, C. C. Organizational Strategy, Structure, and Process, New York: McGraw-Hill, 1978.

Nayyar, P., and Bantel, K. "Competitive Agility: A Source of Competitive Advantage Based on Speed and Variety," Advances in Strategic Management (10A), 1994, pp. 193-222.

Nunnally, J., and Bernstein, I. Psychometric Theory ( $3^{\text {rid }}$ ed.), New York: McGraw-Hill, 1994. Oosterhout, M. V., Waarts, E., and Hillegersberg, J. V. "Assessing Business Agility: A MultiIndustry Study in the Netherlands," in R. Baskerville, L. Mathiassen, J. Pries-Heje, and J. I. DeGross (eds.), Business Agility and Information Technology Diffusion, New York: Springer Science and Business Media, 2005, pp. 275-294.

Podsakoff, P. M., MacKenzie, S. B., Lee, J.-Y. , and Podsakoff, N. P. "Common Method Bias in Behavioral Research: A Critical Review of the Literature and Recommended Remedies," Journal of Applied Psychology (88:5), 2003, pp. 879-903.

Powell, T., and Dent-Micallef, A. "Information Technology as Competitive Advantage: The Role of Human, Business and technology Resources," Strategic Management Journal (18:5), 1997, pp. 375-405.

Prasarnphanich, P., and Gillenson, M. "The Hybrid Click and Bricks Business Model," Communications of the $A C M(46: 2), 2003$, pp. 178-185.

Sabherwal, R., and Chan, Y. E. "Alignment Between Business and IS Strategies: A Study of Prospectors, Analyzers, and Defenders," Information Systems Research (12:1), March 2001, pp. 11-33.

Sambamurthy, V., Bharadwaj, A.S., and Grover, V. "Shaping Agility Through Digital Options: Reconceptualizing The Role of Information Technology in Contemporary Firms," MIS Quarterly (27:2), June 2003, pp. 237-263.

Samli, A. Retail Marketing Strategy: Planning, Implementation, and Control, New York: Quorum Books, 1989.

Sanchez, R. "Building Blocks for Strategy Theory: Resources, Dynamic Capabilities and Competences," in T. Elfring and H. W. Volberda (eds.), Rethinking Strategy, Thousand Oaks, CA: Sage Publications, 2001.

Starr, R., Newfrock, J., and Delurey, M. "Enterprise Resilience: Managing Risk in the Network Economy," Strategy+Business, Spring 2003, pp. 1-10. (retrieved on February 22, 2006 from www.boozallen.de/scm/downloads/201.pdf).

Steinfield, C., Bouwman, H., and Adelaar, T. "The Dynamics of Click-And-Mortar Electronic Commerce: Opportunities And Management Strategies," International Journal of Electronic Commerce (7:1), 2002, pp. 93-119.

Straub, D. W., and Watson, R. T. "Research Commentary: Transformational Issues in Researching IS and Net-enabled Organizations," Information Systems Research (12:4), 2001, pp. 337-345.

SubbaNarasimha, P. "Strategy in Turbulent Environments: The Role of Dynamic Competence," Managerial and Decision Economics (22), 2001, pp. 201-212.

Tallon, P. P., Kraemer, K. L., and Gurbaxani, V. "Executives' Perceptions of the Business Value of Information Technology: A Process-Oriented Approach," Journal of Management Information Systems (16:4), Spring 2000, pp. 145-173.

Venkatraman, N. "Strategic Orientation of Business Enterprises: The Construct, Dimensionality, and Measurement," Management Science (35:8), August 1989, pp. 942-962. 
Vickery, S., Droge, C., and Markland, R. "Dimensions of Manufacturing Strength in the Furniture Industry," Journal of Operations Management (15:4) 1997, pp. 317-330.

Volberda, H. W. "Toward the Flexible Form: How to Remain Vital in Hypercompetitive Environments," Organization Science (7:4), July-August 1996, pp. 359-374.

Wade, M., and Hulland, J. "Review: The Resource-Based View and Information Systems Research: Review, Extension, and Suggestions for Future Research," MIS Quarterly (28:1), March 2004, pp. 107-142.

Wallace, D. W., Giese, J. L., and Johnson, J. L. "Customer Retailer Loyalty in the Context of Multiple Channel Strategies," Journal of Retailing (80), 2004, pp. 249-263.

Weick, K. The Social Psychology of Organizing, New York: McGraw-Hill, 1979.

Wheeler, B. C. "NEBIC: A Dynamic Capabilities Theory for Assessing Net-Enablement," Information Systems Research (13:2), June 2002, pp. 125-146.

Zajac, E. J., Kraatz, M. S., and Bresser, K. "Modeling the Dynamics of Strategic Fit: A Normative Approach to Strategic Change," Strategic Management Journal (21), 2000, pp. 429-453.

\section{About the Authors}

Lih-Bin $\mathrm{Oh}$ is an instructor and doctoral candidate in the Department of Information Systems at the National University of Singapore. He obtained his M.Sc. in Information Systems and B.Sc. (First Class Honors) in Computer and Information Sciences from NUS in 2000 and 1998 respectively. He was a visiting scholar at the Eli Broad Graduate School of Management, Michigan State University, from August to December 2005. Prior to pursuing an academic career, he worked as a program officer in the division of information and communications sciences for the Agency for Science, Technology and Research (A*STAR). His current research interest is in the area of business value of IT in net-enabled organizations. Lih-Bin can be reached at ohlb@comp.nus.edu.sg.

Hock-Hai Teo is an associate professor of Information Systems in the Department of Information Systems at the National University of Singapore. He received his Ph.D. in MIS from NUS in 1998. He was a visiting scholar at the Wharton Business School, University of Pennsylvania from 1999 to 2000 . He has published in the MIS Quarterly, Journal of Management Information Systems, IEEE Transactions on Engineering Management, International Journal of Human-Computer Studies, Journal of the American Society for Information Science and Technology, Journal of Educational Computing Research, Information and Management, and Journal of Database Management. He was the winner of the MIS Quarterly Reviewer of the Year Award (2004). He is currently serving on the editorial boards of MIS Quarterly, IEEE Transactions on Engineering Management, and the Journal of Electronic Commerce Research. Hock-Hai can be reached at teohh@comp.nus.edu.sg. 